studentom, szczególnie zaś tym, którzy lubią przysłowiową „drogę na skróty”, bo ta książka jest najlepszym do tego instruktarzem.

Edyta Głowacka-Sobiech

\title{
Adam Fijałkowski, Tradycja $i$ nowatorstwo w Orbis sensualizm pictus Jana Amosa Komeńskiego, Warszawa 2012, Wydawnictwo UW, ss. 410
}

DOI: 10.14746/BHW.2014.31.15

W ostatnich latach w polskiej historiografii oryginalnych prac poświęconych edukacji i wychowaniu człowieka w XVII w. mamy niewiele. Tylko nieliczne, najczęściej uniwersyteckie ośrodki naukowe mogą poszczycić się takimi osiągnięciami. $Z$ wielką radością należy więc przyjąć kolejną nową publikację Adama Fijałkowskiego, dra hab. Uniwersytetu Warszawskiego, poświęconą pedagogice Jana Amosa Komeńskiego, który przez parę dziesiątków lat powiązany był z Polską, zwłaszcza z Lesznem, Gdańskiem i Elblągiem.

Książka jest niezwykle wnikliwym i dojrzałym studium monograficznym poświęconym jednej z najbardziej znanych publikacji Jana Amosa Komeńskiego, w której podjął bardzo interesującą próbę wykorzystania ilustracji (rysunku) jako narzędzia (sposobu) ułatwiającego poznanie treści (pojęciowego zasobu) użytego w zdaniu krótkiej czytanki łacińskiego słowa - w tłumaczeniu na język ojczysty ucznia. Cały ten zabieg metodyczny miał ułatwić uczniom poznanie i właściwe zrozumienie dziesiątków i setek łacińskich słówek, które stanowiły podstawę uczenia się. Za punkt wyjścia w poszukiwaniu owego „,nowatorstwa pedagogicznego” przyjął Autor pierwsze wydanie Orbis sensualizm pictus - owej niezbyt obszernej książeczki, którą Komeński wydał własnym sumptem w Norymberdze w 1658 r., a więc blisko 360 lat temu - wykorzystując najnowsze zdobycze techniki sztuki drukarskiej tamtych lat - w nadziei, że dzięki niej ułatwi uczniom naukę początkową łaciny, której z takim mozołem uczyły się narażeni nierzadko na karę cielesną za małe postępy w uczeniu się słówek. Faktem jest, że Orbis pictus spośród licznych jego dzieł stał się „najważniejszy” i uznaje się za „pierwowzór” podręcznika do nauki początkowej. Do końca XVIII w., doczekał się ponad 200 wznowień i był tłumaczony na 20 języków świata (zob. „Wstęp”, s. 9).

Autorowi tej publikacji, jak pisze we „Wstępie” - zależało nie na przypominaniu udziału Komeńskiego w działalności politycznej, jako biskupa i przywódcy duchowego braci czeskich w Polsce, bo ta znana jest z badań i prac Łukasza Kurdybachy, Bogdana Suchodolskiego, Tadeusza Bieńkowskiego i innych, ale zależało mu, w oparciu o nowe źródła na doprecyzowaniu znanych już faktów dotyczących genezy i treści Orbis pictus, a także na próbie znalezienia możliwie pełnej odpowiedzi na pytanie o przyczyny tak dużej popularności tego podręcznika i ustaleniu, $w$ jakim stopniu wpisywat się on we wcześniejsza tradycję szkolna, a w jakim byt rzeczywiście innowacyjny (s. 14-15).

Tak więc, badany przez Autora Orbis pictus traktowany jest jako element mikro-historii, która swe możliwości poznawcze i dydaktyczne czerpie z mikroskopowego oglądu, 
z pomniejszenia skali obserwacji, czego klasycznym przykładem może być książeczka Emmanuela Le Roy Ladurie o pirenejskiej wiosce heretyków z przełomu XIII i XIV w., w której zastosowana metoda dotycząca przestrzeni historycznej może być wykorzystana w odniesieniu także do jednego „podręcznika”, jaki dzięki swej popularności, może się stać przykładem ukazującym większe przemiany cywilizacyjne i kulturowe, odwołując się do wybitnych polskich znawców tej formuły metodologicznej jak np. Henryk Samsonowicz, Czesław Majorek czy Jan Topolski (s. 15).

W związku ze sformułowanymi celami badawczymi i przyjętą metodologią badań Autor nadał swojej książce następującą strukturę wewnętrzną. Całość rozważań, poza „Wstępem” i „Zakończeniem”, zawarł w 9 rozdziałach. W celu przybliżenia Czytelnikowi merytorycznej treści pracy wymienię tylko ich tytuły i główne tezy, jakie Autor we „Wstępie” wyeksponował jako wiodące, a mianowicie:

Rozdział I to początki drogi do Orbis pictus: doświadczenia dzieciństwa, szkoły i studiów; tu przez krytyczna analizę doświadczeń Komeńskiego w okresie dzieciństwa i studiów ukazano, w jakim stopniu miały one wpływ na ocenę szkoły, którą - m.in. przez podręczniki, nauczycieli oraz zmianę metod i treści nauczania - chciał reformować.

Rozdział II ukazuje drogę do Orbis pictus przez dające się ustalić lektury swych profesorów - dydaktyków; przez szczegółową ich analizę Autor stara się znaleźć odpowiedź na pytanie: W jakim stopniu Komeński „,powtarzał”, a w jakim „twórczo rozwijał myśl” swoich nauczycieli.

Rozdział III poświęcony został bliższej analizie istniejących w tym czasie podręczników szkolnych w konfrontacji z Orbis pictus. Autor przy tej okazji, w syntetycznej formie rozwinął myśl najbardziej znaczących autorów tekstów humanistycznych tej miary dydaktyków, co: Jan Ludwik Vives, Jan Sturm i Nikodem Frischlin. Przez analizę ich podręczników chciał ustalić różnice i podobieństwa, by znaleźć odpowiedź na pytanie: Na czym polegało rzeczywiste nowatorstwo Komeńskiego?

Rozdział IV jest interesującą próbą poszukiwania związków Orbis pictus Komeńskiego z dydaktyką uprawianą przez jezuitów. Tu Autor poszukuje ponad granicami wyznaniowymi istniejących i możliwych związków pedagogiki jezuickiej i protestanckiej. Bardziej wyraźnie koncentruje się na znanej pedagogice polskiego jezuity Grzegorza Knapiusza (Knapa) pochodzącego z rodziny mieszczańskiej z Grodziska na Mazowszu, jak również na oryginalnym podręczniku Ianua linguarum irlandzkiego jezuity Williama Bathe`a i włoskiego jezuity z Mantui, Antonio Possevino, znanego pisarza, dyplomaty i zagorzałego polemisty w walce $\mathrm{z}$ reformacją.

Rozdział V, zatytułowany: „Wielcy 'Wielkiego Wieku' a Orbis pictus” jest bardzo ciekawą próbą ukazania (także jedynie w syntetycznej formie) wpływu owych wielkich nowożytnych myślicieli, jak Francis Bacon, René Deskartes (Kartezjusz), Tommaso Campanella i Johann Andrea na Komeńskiego i na jego twórczość pedagogiczną, zwłaszcza na jego poglądy zawarte w Wielkiej Dydaktyce, natomiast rozdział VI, jest podobną i niezwykle ciekawą próbą wnikliwego prześledzenia związków i wpływów akademickiego środowiska Gdańska i Elbląga z Samuelem Hartlibem i Joahimem Hübnerem na czele, na drukarstwo i powstawanie tak bogato ilustrowanego podręcznika szkolnego, jakim były prace nad Orbis pictus. 
Szczególne miejsce zajmuje rozdział VII, ukazujący Orbis pictus jako podręcznik o realnym świecie w obrazach, który jednocześnie zawiera jego szczegółową, krytyczną analizę treści. Tu Autor stara się dokładnie określić związek tego podręcznika z wcześniejsza tradycja szkolna i wydobyć owo „nowatorstwo” w dydaktyce badanej epoki podkreślając, że właśnie w tym podręczniku tekst i obraz tworza jednq catość, ale i to, że zawarta w nim została określona wizja świata i spoteczeństwa.

Rozdział VIII jest dalszym uszczegółowieniem badanego „nowatorstwa” przez zastosowanie przez Komeńskiego w nauczaniu początkowym, „Żywego alfabetu” i vocem varia animanitum - tradycja i innowacja, której początki sięgają czasów starożytnych Warrona i Swetoniusza, a także tradycji szkolnej średniowiecza i odrodzenia.

Wreszcie ostatni, IX rozdział ukazuje Orbis pictus w kontekście dziejów komunikacji społecznej, jaka dzięki ciągłemu doskonaleniu druku i technik ilustratorstwa już w drugiej połowie XVII w. zdołała doprowadzić do wielkiej popularności dzieła Komeńskiego.

W „Zakończeniu”, Autor syntetycznie podsumowuje wyniki swoich badań, akcentując szczególnie te wątki, które dają odpowiedź na sformułowane we „Wstępie” cele poznawcze i kluczowe pytania, a także te, które szczególnie podkreślają ów polski wątek w życiu Komeńskiego związany z Lesznem, Gdańskiem i Elblągiem.

Znakomitym dopełnieniem całości naukowych analiz i rozważań, niejako dokumentujących głębię erudycyjnych i poznawczych rozważań Autora, nie tylko w zakresie znajomości łaciny, ale i innych nowożytnych języków jest imponująca bibliografia (30 stron drobnego druku), podzielona na źródła i opracowania, w której dominującym akcentem są niezwykle starannie dopracowane informacje o wykorzystanych publikacjach wydanych w języku polskim, ale także łacińskim, niemieckim, angielskim, francuskim i czeskim.

Warto też zauważyć, że wśród nich jest bardzo wiele prac wydanych w XXI w., co także oznacza, że Autor w swoich niezwykle wnikliwych i ciekawych tak w sensie poznawczym, jak i metodologicznym, w szerokim zakresie uwzględnił najnowsze wyniki rodzimych i światowych badań naukowych.

W tym miejscu warto też zwrócić uwagę, że książka Adama Fijałkowskiego, poza walorami poznawczymi i metodologicznymi, napisana jest znakomitym językiem, z doskonałym wyczuciem przestrzeni czasu w rozwoju naszej cywilizacji, jak również ma wielką swobodę, a nierzadko i swadę w precyzyjnie budowanej narracji, co w sumie znakomicie ułatwia jej zgłębianie.

W sumie uważam, że prezentowana książka Adama Fijałkowskiego jest znakomitą publikacją. Ze względu na jej walory poznawcze, a zwłaszcza na warsztatowe i metodologiczne, w sposób trwały wzbogaca naszą wiedzę nie tylko o Janie Amosie Komeńskim, ale i doskonałym jego podręczniku początkowej fazy nauki szkolnej. Jestem przekonany, że wejdzie ona do kanonu najcenniejszych polskich prac traktujących o historii dydaktyki XVII w.

Karol Poznański 